\title{
Molecular Features of Humic Acids and Fulvic Acids from Contrasting Environments
}

\author{
Judith Schellekens, ${ }^{*}+\odot$ Peter Buurman, ${ }^{\ddagger}$ Karsten Kalbitz, ${ }^{\S, \|}$ Andre van Zomeren, ${ }^{\perp}$ Pablo Vidal-Torrado, ${ }^{\dagger}$ \\ Chiara Cerli," and Rob N.J. Comans \\ †Department of Soil Science (LSO), "Luiz de Queiroz" College of Agriculture (ESALQ), University of São Paulo (USP), Av. Pádua \\ Dias, 11 Caixa Postal 9 Piracicaba/SP 13418-900, Brazil \\ ${ }^{\ddagger}$ Department of Soil Quality, Wageningen University, P.O. Box 47, 6700 AA Wageningen, The Netherlands \\ ${ }^{\S}$ Earth Surface Science, Institute for Biodiversity and Ecosystem Dynamics, University of Amsterdam, Science Park 904, 1098 XH \\ Amsterdam, The Netherlands \\ "Soil Resources and Land Use, Technical University Dresden, Pienner Strasse 19, D-01737 Tharandt, Germany \\ ${ }^{\perp}$ Energy research Centre of The Netherlands, P.O. Box 1, 1755 ZG Petten, The Netherlands
}

ABSTRACT: Insight in the molecular structure of humic acid (HA) and fulvic acid (FA) can contribute to identify relationships between their molecular properties, and further our quantitative abilities to model important organic matter functions such as metal complexation and association with mineral surfaces. Pyrolysis gas chromatography/mass spectrometry (Py-GC-MS) is used to compare the molecular composition of HA and FA. A systematic comparison was obtained by using samples from different environmental sources, including solid and aqueous samples from both natural and waste sources. The chemical signature of the pyrolysates was highly variable and no significant difference between HA and FA was found for major chemical groups, that is,

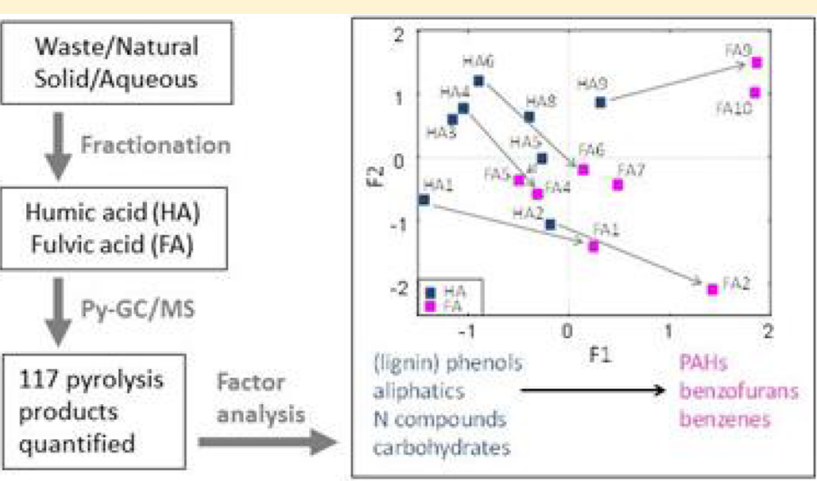
carbohydrates, phenols, benzenes, and lignin phenols, together accounting for $62-96 \%$ of all quantified pyrolysis products. However, factor analysis showed that within each sample, FAs consistently differed from corresponding HAs in a larger contribution from mono- and polyaromatic hydrocarbons and heterocyclic hydrocarbons, together accounting for 3.9-44.5\% of the quantified pyrolysis products. This consistent difference between FAs and corresponding HAs, suggests that their binding properties may, in addition to the carboxyl and phenolic groups, be influenced by the molecular architecture. Py-GC-MS may thus contribute to identify relationships between HA and FA binding- and molecular-properties.

\section{INTRODUCTION}

Natural organic matter (NOM) in soil and water plays a key role in environmental biogeochemical processes. NOM is important in agricultural studies by its role in soil fertility, ${ }^{1}$ environmental risk assessment studies by the interactions of NOM with inorganic and organic contaminants, ${ }^{2,3}$ and in understanding the global carbon cycle and its relation to climate change. ${ }^{4} \mathrm{NOM}$ is a varying complex mixture of several input materials with different degradation states and different mean residence times in the environment. ${ }^{5}$ In attempts to develop a better understanding of the properties of this heterogeneous and complex organic material, it has traditionally been separated into several operationally defined fractions, including humic acid (HA), fulvic acid (FA), and humin. HAs are insoluble under acidic conditions but soluble at higher $\mathrm{pH}$, whereas FAs are soluble under both acid and alkaline conditions. ${ }^{6,7}$

Specific properties have been ascribed to HAs and FAs. Deprotonation of acidic functional groups results in a negative charge, which is generally higher for FAs than that for corresponding HAs from the same sample. ${ }^{8-10}$ As a consequence of the higher negative charge and smaller size, ${ }^{11}$ FAs have enhanced water solubility. Despite the heterogeneous composition of HAs and FAs, ${ }^{3}$ proton binding parameters for carboxylic and phenolic groups in HA and FA isolated from natural and waste materials have been shown to be similar and to fall within the range of generic values for (natural) HA and FA. ${ }^{9}$ Therefore, HAs and FAs have been successfully used to model binding properties to predict the dynamics of pollutants in the environment. ${ }^{12-19}$ However, binding properties still show substantial variation between individual HAs and FAs. ${ }^{10}$ The focus of NOM-pollutant modeling studies is on explaining differences in carboxyl and phenolic functional groups of these

Received: August 4, 2016

Revised: December 4, 2016

Accepted: January 5, 2017 
fractions, and on comparison of models using different assumptions for the "molecular structure" of HA and FA materials. ${ }^{20}$ While, until the 1990s, "humic substances" (including humic fractions) were considered to be unique, new, macromolecular compounds, it is now understood that they are in fact varying mixtures of identifiable molecules that can be attributed to plant and microbial sources. ${ }^{21,22}$ The importance of this new view on humic substances for improving adsorption models has been documented, ${ }^{14}$ and a large amount of literature is available on the chemical characterization of HAs and FAs from natural environments. $3,7,23-25$ However, the complex and heterogenic composition of NOM makes its analysis intricate, ${ }^{26}$ and detailed molecular characterization of HA and FA fractions mostly used a few samples, ${ }^{23,27-33}$ or a single fraction (HA or FA) for several samples, ${ }^{34-37}$ thereby limiting identification of possible generic molecular characteristics of HAs and FAs. Furthermore, the operational definition of HA and FA inevitably makes their quantitative separation and characterization dependent on the extraction procedure, ${ }^{38}$ which complicates comparing the results of different studies.

It has been shown that determination of functional groups with ${ }^{13} \mathrm{C}$ nuclear magnetic resonance can be used to improve parameters for models that predict the proton binding behavior of humic substances in the environment. ${ }^{8}$ Because the location of a carboxyl group determines its dissociation, we hypothesize that the molecular composition of HA and FA materials may differ, reflecting the basic architecture to which these functional groups are associated. Given the diversity in NOM from different environments and the complexity of the transformation processes involved, a detailed and systematic approach is required. To identify differences and similarities in molecular structure between HAs and FAs, a number of samples were isolated from widely different environments, including terrestrial and aquatic ecosystems as well as waste materials. Pyrolysis gas chromatography/mass spectrometry (Py-GC-MS) was chosen to characterize the purified HA and FA fractions. Analytical pyrolysis techniques provide detailed molecular information by breaking larger molecules into fragments using heat in an inert atmosphere; these fragments can thereafter be separated and identified by GC/MS. The technique has been valuable in the interpretation of NOM in the environment. ${ }^{39-43}$ We have determined the molecular composition of a range of HA and FA fractions from different environmental sources that are extracted with the same method, with the purpose to (i) compare HA and FA chemical composition at the molecular level (ii) investigate whether systematic differences in molecular structure between HA and FA can be identified (iii) examine possible implications of these findings for the use of these operationally defined fractions to understand specific functions of NOM in terrestrial and aquatic ecosystems.

\section{EXPERIMENTAL SECTION}

2.1. Sample Description. Samples from both aquatic and solid environments were selected (Table 1). Aquatic samples from natural environments included water from Suwannee River and from a dissolved organic matter rich pond in a nature reserve (Zwanenwater, The Netherlands). Other aquatic samples were collected from a landfill site (Nauerna, The Netherlands) and included leachate from a specific landfill cell and influent water of the landfill wastewater treatment plant. Solid samples from natural environments included peat (Devoke, UK) and two reference soils (Eurosoil 4, an Orthic
Table 1. Sample Origin and Analysed Organic Matter Fraction

\begin{tabular}{|c|c|c|c|c|c|}
\hline source & sample name & & & fraction & $\begin{array}{l}\mathrm{HA} / \\
\mathrm{FA}^{a}\end{array}$ \\
\hline soil (FR) & Eurosoil & solid & natural & HA & \\
\hline soil (U.S.) & Elliot Soil & solid & natural & $\begin{array}{l}\mathrm{HA}, \\
\mathrm{FA}\end{array}$ & 1.73 \\
\hline peat (UK) & Devoke & solid & natural & $\begin{array}{l}\text { HA, } \\
\text { FA }\end{array}$ & 40.7 \\
\hline river (U.S.) & $\begin{array}{l}\text { Suwannee } \\
\text { River }\end{array}$ & aquatic & natural & $\begin{array}{l}\mathrm{HA}, \\
\mathrm{FA}\end{array}$ & \\
\hline $\begin{array}{l}\text { dissolved organic } \\
\text { matter-rich pond in } \\
\text { nature reserve }(\mathrm{NL})\end{array}$ & Zwanenwater & aquatic & natural & $\begin{array}{l}\text { HA, } \\
\text { FA }\end{array}$ & 0.23 \\
\hline $\begin{array}{l}\text { compost from } \\
\text { municipal waste } \\
(\mathrm{NL})\end{array}$ & compost & solid & waste & HA & 25.7 \\
\hline \multicolumn{6}{|l|}{$\begin{array}{l}\text { landfill waste, } \\
\text { Nauerna (NL) }\end{array}$} \\
\hline Influent & $\begin{array}{l}\text { Nauerna } \\
\text { influent }\end{array}$ & aquatic & waste & $\begin{array}{l}\text { HA, } \\
\text { FA }\end{array}$ & 0.07 \\
\hline landfill waste & LYS & solid & waste & $\begin{array}{l}\text { HA, } \\
\text { FA }\end{array}$ & 6.22 \\
\hline leachate & Nauerna 13AA & aquatic & waste & FA & 0.05 \\
\hline $\begin{array}{l}\text { landfill waste burning } \\
\text { residue "bottom ash } \\
\text { NL 2005" (Alkmaar, } \\
\text { NL) }\end{array}$ & HVC & solid & waste & FA & \\
\hline
\end{tabular}

Luvisol from Normandy, France, ${ }^{44}$ and Elliot Soil, a fine, illitic, mesic Aquic Arguidolls soil from Illinois), while waste samples included compost from green waste (The Netherlands), a landfill waste mixture from Nauerna (The Netherlands) consisting mainly of soil remediation sludge, contaminated soil, industrial sludge, and construction and demolition waste (LYS), and bottom ash (HVC) from a municipal solid waste incineration plant (Alkmaar, The Netherlands). The samples from Elliot Soil and Suwannee River are standard "humic substances" and were obtained from the International Humic Substances Society (IHSS; http://www.humicsubstances.org/ sources.html). ${ }^{38}$

2.2. Isolation of HAs and FAs. The described solid and aquatic samples (Table 1) were extracted using an automated procedure that is described in detail elsewhere. ${ }^{45}$ Basically, the developed equipment automates the fractionation method of Aiken, ${ }^{46}$ earlier described in detail by Thurman and Malcolm, ${ }^{47}$ for isolation and purification of HA and FA standards from aqueous samples. The equipment was also used to extract HA and FA from solid samples using the method of Swift ${ }^{48}$ for solid source materials. Both procedures are adapted by the IHSS.

2.3. Py-GC-MS. All samples were analyzed in duplicate with Py-GC-MS. Pyrolysis was performed at the Department of Soil Science from ESALQ/USP (Piracicaba, Brazil) using a single shot PY-3030S pyrolyser (Frontier Laboratories, Japan) coupled to a GCMS-QP2010 (Shimadzu, Japan). The pyrolysis temperature was set at $600{ }^{\circ} \mathrm{C}\left( \pm 0.1^{\circ} \mathrm{C}\right)$; Helium was used as carrier gas. The injection temperature of the GC (operated in 1:20 split mode) and the GC/MS interface were set at $320^{\circ} \mathrm{C}$. The GC oven was heated from 50 to $320^{\circ} \mathrm{C}$ (held $10 \mathrm{~min}$ ) at 7 ${ }^{\circ} \mathrm{C} \mathrm{min}^{-1}$. The GC instrument was equipped with a UltraAlloy5 column (Frontier Laboratories Ltd.), length $30 \mathrm{~m}$, thickness $0.25 \mathrm{~mm}$, diameter $0.25 \mu \mathrm{m}$. The MS was scanning in the range of $m / z$ 45-600. Pyrolysis products were identified using the NIST '14 library. 
Table 2. Pyrolysis Products Used in Factor Analysis (Figure 2)

\begin{tabular}{|c|c|c|c|c|c|c|c|}
\hline & pyrolysis product $^{a}$ & $m / z^{b}$ & group $^{c}$ & & pyrolysis product $^{a}$ & $m / z^{b}$ & group $^{c}$ \\
\hline 1 & 2-methylfuran & 53,82 & Ps & 38 & $\mathrm{C}_{2}$ 1,3-isobenzofurandione & 104,176 & $\mathrm{Bf}$ \\
\hline 2 & benzene & 77,78 & B & 39 & dibenzofuran & 139,168 & $\mathrm{Bf}$ \\
\hline 3 & acetic acid & 60 & Ps & 40 & 4-ethylsyringol & 167,182 & $\mathrm{Lg}$ \\
\hline 4 & pyridine & 52,79 & $\mathrm{~N}$ & 41 & 1,3-isobenzofurandione compound & 76,104 & $\mathrm{Bf}$ \\
\hline 5 & pyrrole & 67 & $\mathrm{~N}$ & 42 & 4-(propane-2-one)guaiacol & 137,180 & $\operatorname{Lg}$ \\
\hline 6 & toluene & 91,92 & B & 43 & levoglucosan & 60,73 & Ps \\
\hline 7 & 2-furaldehyde & 95,96 & Ps & 44 & 4-vinylsyringol & 165,180 & $\mathrm{Lg}$ \\
\hline 8 & $\mathrm{C}_{2}$ benzene & 91,106 & B & 45 & $\mathrm{C}_{2}$ 1,3-isobenzofurandione & 104,176 & $\mathrm{Bf}$ \\
\hline 9 & $\mathrm{C}_{2}$ benzene & 91, 106 & B & 46 & $\mathrm{C}_{3}$ naphthalene & 155,170 & $\mathrm{PAH}$ \\
\hline 10 & styrene & 78,104 & $\mathrm{~B}$ & 47 & fluorene & 165,166 & $\mathrm{PAH}$ \\
\hline 11 & $\mathrm{C}_{2}$ benzene & 91,106 & B & 48 & diethyl phthalate & 149,177 & $\mathrm{Pt}$ \\
\hline 12 & acetamide & 59 & $\mathrm{~N}$ & 49 & vanillic acid & 153,168 & $\operatorname{Lg}$ \\
\hline 13 & 5-methyl-2-furaldehyde & 109,110 & Ps & 50 & $\mathrm{C}_{1}$ dibenzofuran & 181,182 & $\mathrm{Bf}$ \\
\hline 14 & benzonitrile & 76,103 & $\mathrm{~N}$ & 51 & $\mathrm{C}_{3}$ syringol & 91,194 & $\operatorname{Lg}$ \\
\hline 15 & phenol & 66,94 & $\mathrm{Ph}$ & 52 & diketodipyrrole & 93,186 & $\mathrm{~N}$ \\
\hline 16 & $\mathrm{C}_{3}$ benzene & 105,120 & B & 53 & pristene & 55,69 & $\mathrm{Al}$ \\
\hline 17 & $\mathrm{C}_{1}$ phenol & 107,108 & $\mathrm{Ph}$ & 54 & 4-acetylsyringol & 181,196 & $\operatorname{Lg}$ \\
\hline 18 & guaiacol & 109,124 & $\operatorname{Lg}$ & 55 & phenanthrene & 178 & $\mathrm{PAH}$ \\
\hline 19 & $\mathrm{C}_{1}$ benzofuran & 131,132 & $\mathrm{Bf}$ & 56 & 4-(propane-3-one)syringol & 181,210 & $\operatorname{Lg}$ \\
\hline 20 & naphthalene & 128 & $\mathrm{PAH}$ & 57 & 2,3-naphthalenedicarboxylic acid & 126,154 & $\mathrm{PAH}$ \\
\hline 21 & 4-methylguaiacol & 123,138 & $\operatorname{Lg}$ & 58 & syringic acid & 198,183 & $\operatorname{Lg}$ \\
\hline 22 & $\mathrm{C}_{2}$ benzofuran & 145,146 & $\mathrm{Bf}$ & 59 & $\mathrm{C}_{16} n$-fatty acid & 60,73 & $\mathrm{Al}$ \\
\hline 23 & 4-vinylphenol & 91,120 & $\operatorname{Lg}$ & 60 & $\mathrm{C}_{2}$ phenanthrene & 191,206 & PAH \\
\hline 24 & catechol & 64,110 & $\mathrm{Ph}$ & 61 & phenanthrene compound & 205,220 & $\mathrm{PAH}$ \\
\hline 25 & 4-ethylguaiacol & 137,152 & $\mathrm{Lg}$ & 62 & retene & 219,234 & $\mathrm{PAH}$ \\
\hline 26 & 3-methoxycatechol & 97,140 & $\mathrm{Ph}$ & 63 & phthalate compound & 149,167 & $\mathrm{Pt}$ \\
\hline 27 & $\mathrm{C}_{1}$ naphthalene & 141,142 & $\mathrm{PAH}$ & 64 & $\mathrm{C}_{18} n$-alkylamide & 59,72 & $\mathrm{~N}$ \\
\hline 28 & indole & 90,117 & $\mathrm{~N}$ & 65 & $\mathrm{C}_{8-33} n$-alkanes & 57,71 & $\mathrm{Al}$ \\
\hline 29 & 4-vinylguaiacol & 135,150 & $\operatorname{Lg}$ & 66 & $\mathrm{C}_{8-28} n$-alkenes & 55,69 & $\mathrm{Al}$ \\
\hline 30 & phthalate & 76,104 & $\mathrm{Pt}$ & 67 & $\mathrm{C}_{23,25-29} n$-methyl ketones & 58,59 & $\mathrm{Al}$ \\
\hline
\end{tabular}

syringol

$\mathrm{C}_{1}$ 1,3-isobenzofurandione

$\mathrm{C}_{2}$ naphthalene

benzene acetic acid, 2-carboxy

$\mathrm{C}_{3}$ guaiacol

4-methylsyringol

4-acetylguaiacol
139, $154 \quad \mathrm{Lg}$

90, $118 \quad \mathrm{Bf}$

141, $156 \quad \mathrm{PAH}$

90, $118 \quad$ B

77, $164 \quad \mathrm{Lg}$

153, $168 \quad \mathrm{Lg}$

151, $166 \quad$ Lg

${ }^{a}$ Numbers refer to variables in factor loadings (Figure 2) and pyrolysis products in Figure $1 .{ }^{b}$ Specific fragment ions used for quantification. ${ }^{c}$ Chemical group. $\mathrm{Lg}=$ lignin phenol, $\mathrm{B}=$ benzene, $\mathrm{PAH}=$ polyaromatic hydrocarbon, $\mathrm{Ph}=$ phenol, $\mathrm{Ps}=$ carbohydrate, $\mathrm{Bf}=$ benzofuran, $\mathrm{Pt}=$ phthalate, $\mathrm{Al}=$ aliphatic $N=$ nitrogen containing compound.

All dominant products were selected for quantification; these dominant products were reduced by excluding those products that appeared in only one pyrogram or in pyrograms from only one source sample (Elliot Soil, Nauerna, etc.). In addition to the dominant products, lignin phenols and polyaromatic hydrocarbons (PAHs) were selected for quantification because they may provide useful information on source and decay. ${ }^{42,43}$ This selection resulted in a number of 117 compounds, which were quantified for all samples. Quantification was based on the peak area of characteristic ion fragments $(\mathrm{m} / \mathrm{z}$ values $)$ for each pyrolysis product (Table 2). All quantification was checked manually. For each sample, the sum of the quantified peak areas, expressed as total ion current (TIC), was set at $100 \%$ and relative amounts were calculated with respect to this sum.

2.4. Data Analysis. Factor analysis was used to identify the main trends of pyrolysate composition in the samples. Because it does not differentiate between products with high or low relative abundance, mean values of groups of pyrolysis products are used to give an indication of NOM composition for the three different sample classes, that is, waste/natural, solid/ aqueous and HA/FA fractions. In order to evaluate the contribution from groups of pyrolysis products within these sample classes, an ANOVA test was applied to check for significant differences. Prior to factor analysis, the number of pyrolysis products (variables) was reduced by grouping the $n$ alkanes, $n$-alkenes and $n$-methyl ketones to a single variable (the sum of all products within each group). This grouping has been done because these products were large in number but showed a low relative abundance (only being noteworthy in Devoke HA; Figure 1), and the largest set of correlated variables is allocated to the first factor. This reduction of pyrolysis products resulted in 67 variables for factor analysis (Table 2).

\section{RESULTS AND DISCUSSION}

\subsection{Qualitative Comparison and Source Allocation of} Pyrolysates. Pyrograms for the analyzed HA and FA samples are shown in Figure 1, and show that the composition of the samples was highly variable. The quantified pyrolysis products have been categorized into groups based on their chemical similarity (Table 2 ). The sum of these products for each group provides an indication of the general composition of the samples (Table 3).

Both Nauerna FAs showed a large hump after 17 min (Figure $1 \mathrm{fh}$ ), which results from coelution of complex mixtures of many 

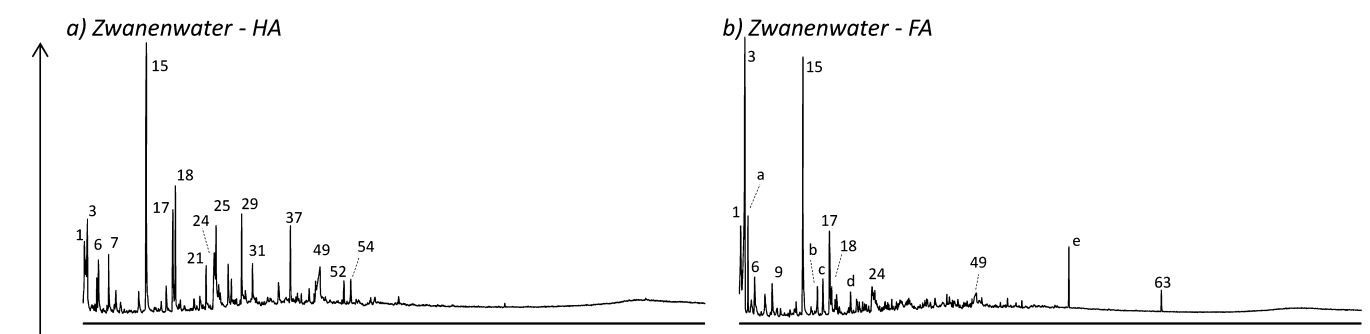

c) Suwannee River - HA

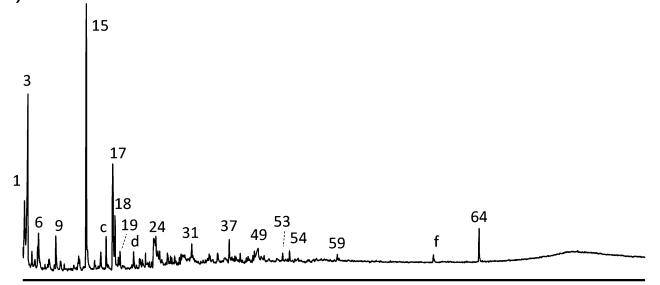

d) Suwannee River - FA

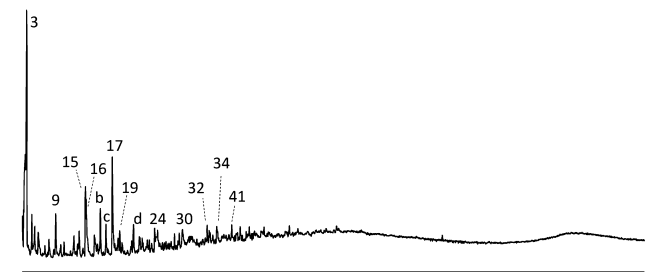

e) Nauerna Influent - HA

f) Nauerna Influent - FA
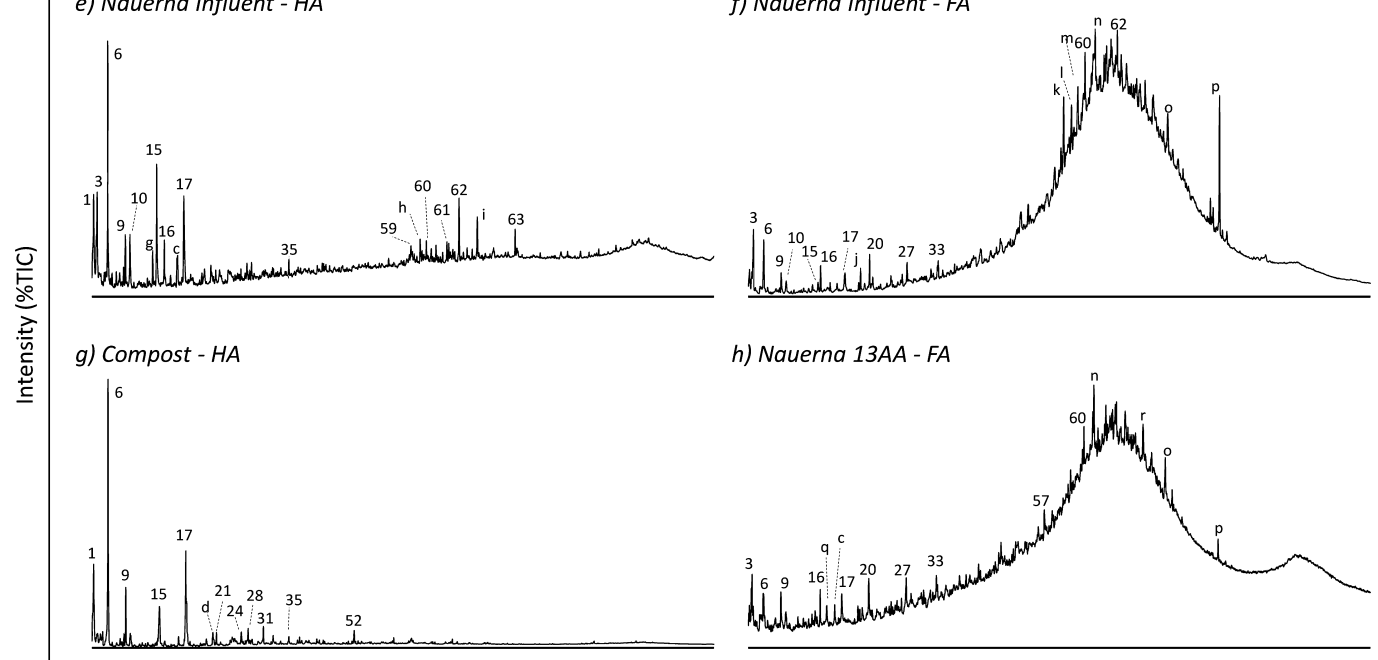

h) Nauerna $13 A A-F A$

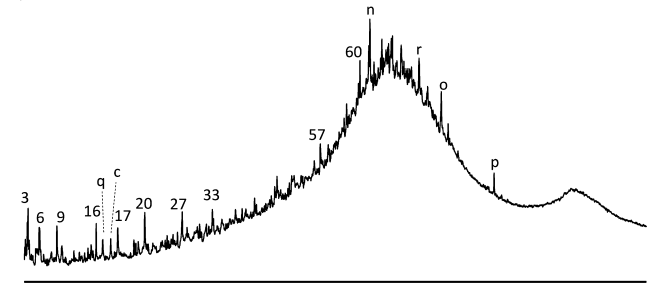

i) Devoke peat - HA

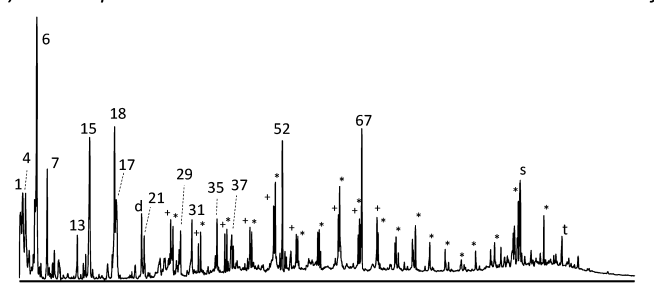

j) Devoke peat - FA

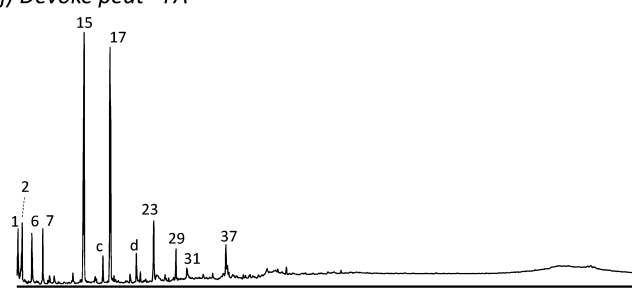

k) Elliot Soil - HA

l) Elliot Soil - FA
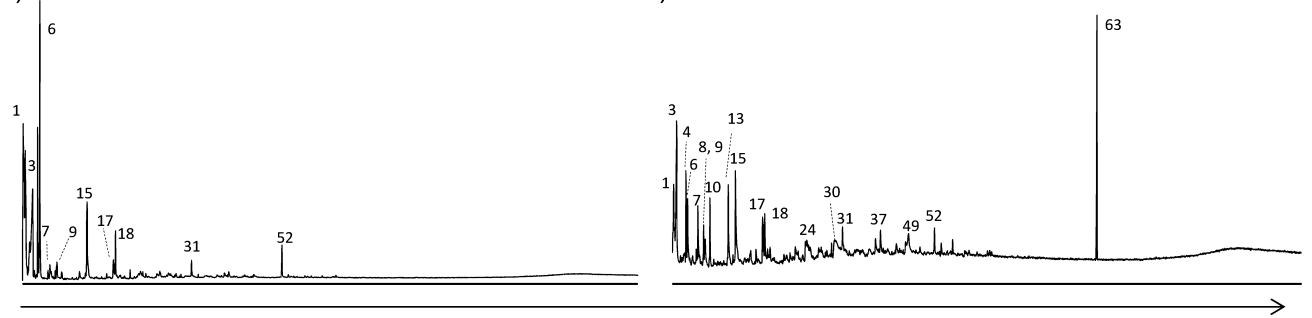

Retention time (min)

Figure 1. continued 


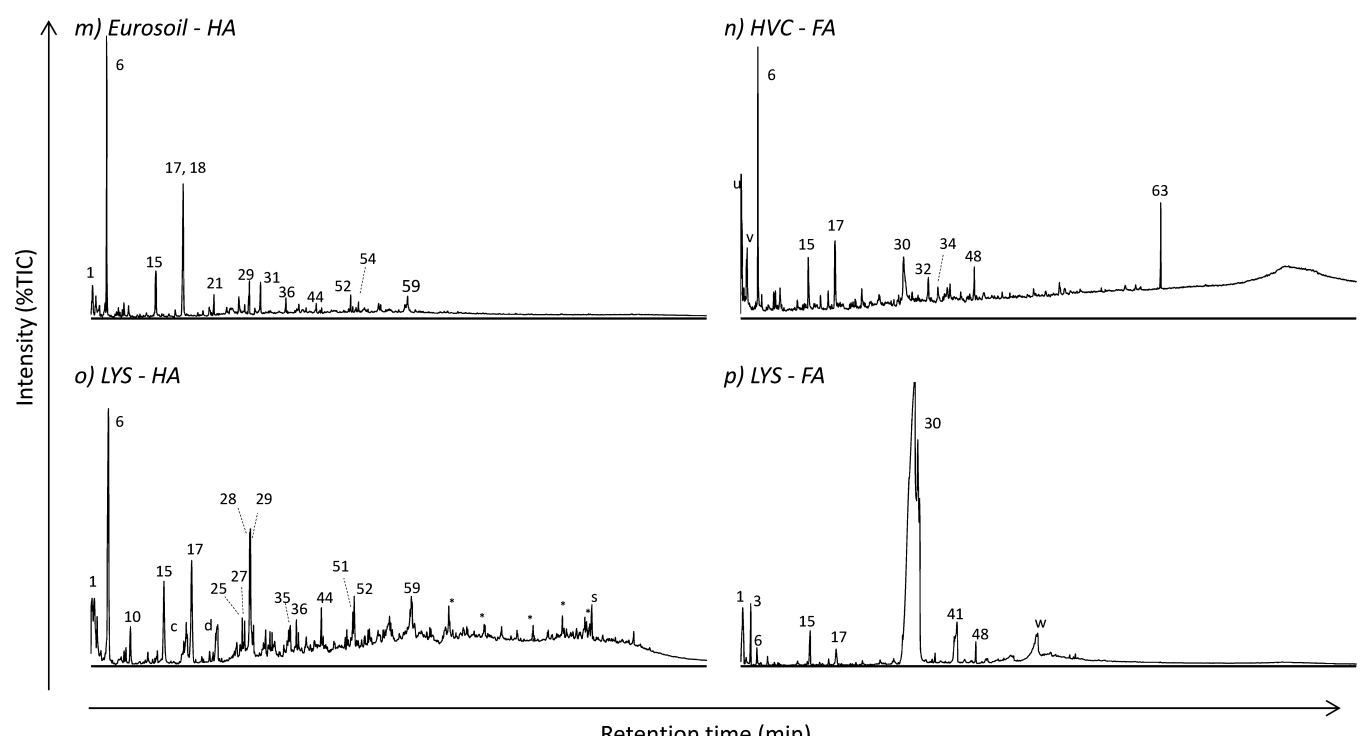

Figure 1. Pyrograms of the analyzed samples. Numbered peak labels correspond to quantified pyrolysis products in Table 2, except for $n$-alkanes and $n$-alkenes that are indicated by “*” and " + ", respectively. Dominant peaks that were not quantified are indicated by a letter and included: a $=$ unidentified compound with $m / z 69,100 ; \mathrm{b}=$ cyclooctene; $\mathrm{c}=\mathrm{C}_{1}$ phenol; $\mathrm{d}=\mathrm{C}_{2}$ phenol; $\mathrm{e}=$ unidentified compound with $m / z 69,253 ; \mathrm{f}=\mathrm{C}_{18}$ alkyl nitrile; $g=$ unsaturated $\mathrm{C}_{3}$ alkyl benzene; $\mathrm{h}=$ unidentified $\mathrm{PAH}$ with $m / z 159,241,256 ; \mathrm{i}=$ unidentified diterpene with $m / z 233,248,109 ;{ }^{79} \mathrm{j}=\mathrm{C}_{5}$ alkyl benzene; $\mathrm{k}=$ unidentified PAH with $\mathrm{m} / z$ 241, 242, 256; 1 = unidentified diterpene with $\mathrm{m} / z 239,240$; ${ }^{79} \mathrm{~m}=$ unidentified diterpene with $\mathrm{m} / z$ 239, 256; $\mathrm{n}=$ abietic acid compound $\mathrm{m} / z 239,254{ }^{79} \mathrm{o}=$ pimaric acid; $\mathrm{p}=$ unidentified $\mathrm{PAH}$ with $\mathrm{m} / z$ 339, 354; $\mathrm{q}=$ indene; $\mathrm{r}=$ unidentified PAH with $m / z 128,129,187$; $\mathrm{s}=$ unidentified sterol with $m / z 147,396 ; \mathrm{t}=$ unidentified sterol with $\mathrm{m} / z 174,410$; $\mathrm{u}=$ unidentified aliphatic with $m / z$ 55, $70 ; \mathrm{v}=$ unidentified aliphatic with $m / z 57,58 ; \mathrm{w}=$ unidentified compound with $m / z 55,83,84,124,152$.

hydrocarbons with similar properties ${ }^{49}$ that cannot be resolved by GC/MS and is a common characteristic during analysis of crude oil. ${ }^{50}$

Benzenes and phenols were dominant groups in most samples (Table 3) and are rather unspecific pyrolysis products that may have multiple sources including lignin, proteins and black carbon (BC). ${ }^{39,43}$ The relative abundance of phthalates was highly variable in the analyzed sample set. Phthalate $(1,2-$ benzenedicarboxylic acid; \#30) was the major peak in LYS FA (about 90\% TIC; Figure 1p). Phthalates are well-known additives to plastics, most likely explaining their abundance in this sample from a solid landfill mainly composed of inorganic waste. ${ }^{10}$ PAHs originate from charred material. ${ }^{42,51}$ Retene (\#62) was abundant in both FA and HA from waste samples and originates from resins. ${ }^{52}$ Benzofurans in NOM pyrolysates usually originate from charred materials. ${ }^{53-55}$ Methoxyphenols originate from lignin; their presence in all samples (Figure 1) evidence vascular plant input, which in the waste samples may originate from industrially processed plant materials. Carbohydrate products may have both plant and microbial sources. Large amounts of acetic acid (\#3) were found in some samples (Figure 1), which usually indicate an abundance of small (partially decomposed) polysaccharide fragments but may also derive from (di)fatty acids. ${ }^{56} \mathrm{~N}$ containing compounds originate from proteins and chitin. ${ }^{57}$ Large numbers of different $\mathrm{N}$-containing compounds in NOM pyrolysates generally indicate a large contribution from microbial material. ${ }^{40,58}$ Pyridine and pyrrole are unspecific $\mathrm{N}$-containing pyrolysis products, benzonitrile is usually related to burning, ${ }^{59}$ acetamide may originate from chitin, ${ }^{60}$ and indole and diketodipyrrole are frequently associated with a plant origin. ${ }^{58}$ Aliphatic pyrolysis products included $n$-alkanes, $n$-alkenes, $n$-methyl ketones, and $n$-fatty acids. Aliphatics in pyrolysates may originate from leaf waxes, ${ }^{61}$ from biopolymers such as cutin/cutan, suberin/ suberan, and algeanan, ${ }^{62,63}$ and also plastics can produce aliphatic pyrolysis products. ${ }^{64}$ Only the HA from the peat (Devoke) showed a considerable amount of $n$-alkanes and $n$ methyl ketones (Table 3; Figure 1i).

3.2. Factor Analysis. The first two factors from factor analysis applied to the HA and FA pyrolysates explained $44.1 \%$ of the total variance. This is within the same range as other studies that applied factor analysis to pyrolysates from related samples from soil and peat $(41-53 \%),{ }^{65-67}$ and large considering the widely different sample sources (waste/natural, solid/aqueous). The projection of loadings for factor 1 (F1) and factor $2(\mathrm{~F} 2)$ is given in Figure 2 and reflects the main chemical differences that underlie the variation between the samples. Products associated with aromatic condensed structures (BC) showed positive loadings on F1 and included benzofurans, PAHs and benzenes, ${ }^{68,69}$ except for toluene (\#6) that is frequently associated with other sources than BC. Compounds with negative loadings on $\mathrm{F} 1$ are typically derived from natural biopolymers and included lignin phenols (from lignin), catechols (from tannin), aliphatic products (from cutan/suberan), ${ }^{63}$ carbohydrates (from hemicellulose and cellulose), ${ }^{70}$ diketodipyrrole (\#52; from plant material), ${ }^{58}$ and pyrrole (\#5) and acetamide (\#12; from microbes ${ }^{60,71}$ ). Thus, F1 is interpreted to reflect the contribution from aromatic condensed structures (positive) and natural biopolymers (negative).

F2 showed a clear separation of benzofurans (high negative loadings) and PAHs (high positive loadings). The larger water solubility of hetero-PAHs such as benzofurans, compared to $\mathrm{PAHs}^{72}$ may indicate that F2 reflects aqueous solubility. PyGC-MS is not the most appropriate method to identify chemical characteristics related to solubility because solubility mainly relates to the amount of functional groups and the molecular size, both of which refer to characteristics of NOM before fragmentation by pyrolysis. Nevertheless, this interpretation of F2 is supported by the loadings of other products. 
Table 3. Relative Proportion of Groups of Pyrolysis Products (\%Tic) For Each Sample (A) And Mean Values for Sample Classes (B)

\begin{tabular}{|c|c|c|c|c|c|c|c|c|c|c|c|c|c|}
\hline & & phenols & benzenes & carbohydrates & $\begin{array}{l}\text { lignin } \\
\text { phenols }\end{array}$ & phthalates & $\begin{array}{c}\mathrm{N} \\
\text { compounds }\end{array}$ & aliphatics $^{a}$ & PAHs & benzofurans & sum & $\begin{array}{c}\text { sum of } \\
\text { major } \\
\text { products } \\
\text { (Ph, B, } \\
\text { Ps, Lg) }\end{array}$ & $\begin{array}{c}\text { sum of } \\
\text { (minor) } \\
\text { products } \\
\text { with positive } \\
\text { loading on } \\
\text { F1 }{ }^{b}\end{array}$ \\
\hline \multicolumn{14}{|l|}{ A } \\
\hline Elliot Soil & HA & 17.7 & 33.6 & 26.2 & 5.36 & 0.00 & 15.4 & 0.62 & 0.79 & 0.39 & 100 & 82.8 & 7.82 \\
\hline Elliot Soil & FA & 21.9 & 13.5 & 24.1 & 9.18 & 18.3 & 10.1 & 0.43 & 1.03 & 1.52 & 100 & 68.6 & 9.83 \\
\hline Devoke & $\mathrm{HA}$ & 24.4 & 22.5 & 13.8 & 10.5 & 0.01 & 7.86 & 19.8 & 0.85 & 0.30 & 100 & 71.2 & 4.93 \\
\hline Devoke & FA & 60.8 & 7.35 & 11.5 & 16.5 & 0.46 & 1.55 & 0.45 & 0.60 & 0.85 & 100 & 96.1 & 4.12 \\
\hline Eurosoil & HA & 27.7 & 36.7 & 5.50 & 20.1 & 0.03 & 5.30 & 3.97 & 0.36 & 0.34 & 100 & 90.0 & 3.92 \\
\hline $\begin{array}{l}\text { Suwannee } \\
\text { River }\end{array}$ & HA & 46.0 & 11.3 & 21.8 & 9.55 & 1.01 & 4.85 & 0.93 & 1.81 & 2.62 & 100 & 88.8 & 10.2 \\
\hline $\begin{array}{l}\text { Suwannee } \\
\text { River }\end{array}$ & FA & 36.3 & 22.1 & 18.3 & 2.52 & 6.04 & 1.58 & 1.16 & 2.79 & 9.28 & 100 & 79.2 & 29.6 \\
\hline Zwanenwater & HA & 41.6 & 7.56 & 18.1 & 23.2 & 0.32 & 5.32 & 1.91 & 0.80 & 1.16 & 100 & 90.5 & 5.10 \\
\hline Zwanenwater & FA & 39.1 & 11.9 & 31.9 & 7.05 & 0.78 & 3.32 & 0.03 & 2.08 & 3.83 & 100 & 90.0 & 13.2 \\
\hline compost & HA & 24.3 & 49.8 & 5.75 & 6.26 & 0.04 & 8.39 & 4.12 & 0.96 & 0.28 & 100 & 86.2 & 8.93 \\
\hline $\begin{array}{l}\text { Nauerna } \\
\text { Influent }\end{array}$ & HA & 27.3 & 41.0 & 10.6 & 6.08 & 1.80 & 5.57 & 1.39 & 5.51 & 0.78 & 100 & 84.9 & 21.8 \\
\hline $\begin{array}{l}\text { Nauerna } \\
\text { Influent }\end{array}$ & FA & 15.1 & 36.2 & 14.8 & 3.43 & 2.95 & 2.87 & 0.00 & 22.4 & 2.27 & 100 & 69.6 & 42.1 \\
\hline Lys & HA & 29.5 & 33.9 & 4.68 & 9.28 & 0.08 & 9.70 & 11.2 & 1.19 & 0.40 & 100 & 77.4 & 6.10 \\
\hline Lys & FA & 2.27 & 0.77 & 2.43 & 0.65 & 93.5 & 0.13 & 0.00 & 0.17 & 0.10 & 100 & 6.12 & 0.52 \\
\hline Nauerna 13AA & FA & 16.5 & 36.4 & 11.5 & 4.18 & 7.65 & 3.88 & 0.00 & 16.7 & 3.19 & 100 & 68.6 & 43.8 \\
\hline HVC & FA & 16.3 & 37.9 & 3.93 & 5.30 & 26.81 & 3.25 & 1.09 & 2.29 & 3.14 & 100 & 63.4 & 15.4 \\
\hline \multicolumn{14}{|l|}{$\mathrm{B}^{c}$} \\
\hline natural & & 35.1 & 18.5 & 19.0 & 11.5 & 2.99 & 6.14 & 3.25 & 1.23 & 2.25 & & & \\
\hline waste & & 18.7 & 33.7 & 7.67 & 5.03 & 19.0 & 4.83 & 2.55 & 7.03 & 1.45 & & & \\
\hline solid & & 25.0 & 26.2 & 10.9 & 9.23 & 15.5 & 6.86 & 4.63 & 0.91 & 0.81 & & & \\
\hline aquatic & & 31.7 & 23.8 & 18.2 & 8.01 & 2.93 & 3.91 & 0.77 & 7.44 & 3.30 & & & \\
\hline HA & & 29.8 & 29.5 & 13.3 & 11.3 & 0.41 & 7.80 & 5.49 & 1.53 & 0.78 & & & \\
\hline FA & & 26.0 & 20.8 & 14.8 & 6.10 & 19.6 & 3.34 & 0.39 & 6.00 & 3.02 & & & \\
\hline
\end{tabular}

${ }^{a}$ Aliphatics included $n$-alkanes, $n$-alkenes, $n$-fatty acids, $n$-methyl ketones and pristene. ${ }^{b}$ Sum of benzofurans, PAHs and aromatics with positive loadings on F1 (Figure 2); note that for the aromatics these include all except toluene. ${ }^{c}$ Average values; significant differences for groups of products are printed in bold for each sample class $(P<0.05$ for the ANOVA test $)$.

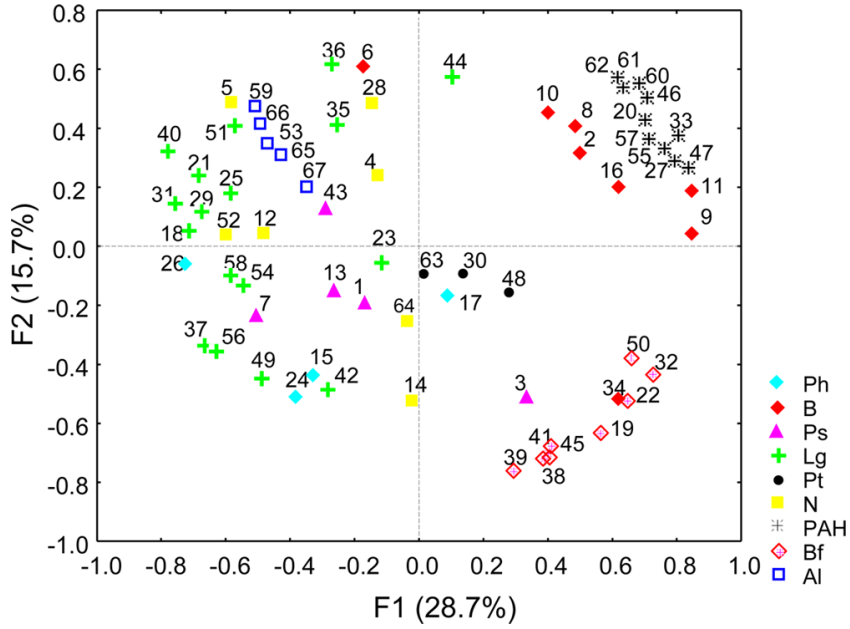

Figure 2. Loadings for the F1-F2 projection of factor analysis applied to the pyrolysates. $\mathrm{Lg}=$ lignin phenol, $\mathrm{B}=$ benzene, $\mathrm{PA}=\mathrm{PAH}, \mathrm{Ph}=$ phenol, $\mathrm{Ps}=$ carbohydrate, $\mathrm{Bf}=$ benzofuran, $\mathrm{Pt}=$ phthalate, $\mathrm{Al}=$ aliphatic $\mathrm{N}=$ nitrogen containing compound. Variable numbers correspond to (groups of) pyrolysis products given in Table 2.

First, phenols and lignin products with oxygenated alkyl side chains (\#37, \#42, \#49, \#54, \#56, \#58) showed negative loadings on F2, while lignin products with a $\mathrm{C}_{3}$ alkyl side chain (\#35, 51) showed positive loadings on F2. This separation of lignin phenols on F2 reflects more decomposed material (negative) from more intact plant biopolymers (positive) because degradation increases oxygenation of lignin alkyl side-chains ${ }^{5}$ and demethylation. ${ }^{73}$ Second, products associated with aliphatic biopolymers (\#64-\#67; cutan/suberan) showed positive loadings on F2. Third, levoglucosan (\#43), a pyrolysis product of cellulose $\mathrm{e}^{70}$ ), showed positive loadings on F2 while other carbohydrates showed negative ones. All three cases demonstrate a relation to size of the source material (referring to the size before pyrolysis), with pyrolysis products from biopolymers (cutan/suberan, lignin and cellulose) showing positive loadings on F2. The positive loadings of the PAHs provide support for this interpretation; the PAH hump in the Nauerna FAs (Figure 1fh) was interpreted as problematically pyrolysable material, which would logically be larger units of condensed aromatic materials. This interpretation of F2 would imply that benzofurans are associated with lower molecular weight material, and presumably incomplete charring, that is, less condensed structures. ${ }^{68}$ A summary of the interpretation of F1 and $\mathrm{F} 2$ is given in Table 4.

3.3. Differences between Environmental Sources and Fractions. Although the chemical signature of the pyrolysates 
Table 4. Interpretation of Statistical Factors Based on Loadings of Pyrolysis Products

\begin{tabular}{|c|c|c|c|}
\hline & interpretation $^{a}$ & negative loadings & positive loadings \\
\hline $\mathrm{F} 1$ & aromaticity & $\begin{array}{l}\text { products from plant polymers } \\
\text { (lignin phenols, phenols, } n- \\
\text { aliphatics, } \mathrm{N} \text { compounds) }\end{array}$ & $\begin{array}{l}\text { products associated with } \\
\text { BC (PAHs, most ben- } \\
\text { zenes, benzofurans) }\end{array}$ \\
\hline $\mathrm{F} 2$ & solubility & $\begin{array}{l}\text { benzofurans, lignin phenols } \\
\text { with oxygenated alkyl side } \\
\text { chains, phenols }\end{array}$ & $\begin{array}{l}\text { PAHs, lignin phenols } \\
\text { with a } \mathrm{C}_{3} \text { alkyl side } \\
\text { chain, } n \text {-aliphatics }\end{array}$ \\
\hline
\end{tabular}

${ }^{a}$ Refers to the material before pyrolysis.

was highly variable (Figure 1), averaged values of groups of compounds displayed some general tendencies. A rough pooling of the molecular composition of the pyrolysates was obtained by averaging the values (percentage of the total quantified peak area) of the different compound groups for three different sample classes, that is, waste/natural, solid/ aqueous and HA/FA (Table 3b). The same sample classes are displayed in factor scores diagrams (Figure 3).

3.3.1. Waste Vs Natural Samples. Significant difference between natural and waste samples for groups of compounds (Table 3b), was found for phenols, benzenes, carbohydrates, and lignin phenols. A larger contribution from phenols, carbohydrates, and lignin products was found in the natural samples, in agreement with plant biopolymers such as lignin and cellulose. Benzenes were significantly more abundant in waste samples. The aquatic samples from Nauerna waste (Influent HA and FA, and Leachate FA) had a particularly large contribution from PAHs (Table 3a), probably reflecting a major contribution from organic contaminants.

In factor analysis, the waste samples generally showed positive scores on F2 (Figure 3a), indicating a larger contribution from polymeric materials compared to natural samples. Waste samples with slightly negative scores on F2 included FAs from solid waste (HVC and LYS); both were associated with phthalates (Table $3 \mathrm{a}$ ), which is consistent with the production of phthalates upon combustion of plastics. ${ }^{74}$

3.3.2. Aquatic vs Solid Samples. Independently of a natural or waste source, a significant difference between solid and aqueous samples was found for PAHs and benzofurans, both being more abundant in aquatic samples (Table 3b). A larger contribution from PAHs in aquatic samples agrees with abundant dissolved BC in rivers reported by recent studies, ${ }^{54,75,76}$ and is in agreement with a relative increase of more refractory materials upon degradation, considering the fact that terrestrial dissolved organic matter is the result of biological degradation. $^{26}$

Factor analysis explains the absence of significant differences for most groups of pyrolysis products between aquatic and solid samples by two observations (Figure 3b). First, the aquatic samples showed a clear separation of natural and waste samples in factor analysis on F2. Second, F2 reflects the water solubility of source materials, which was not particularly related to a specific chemical group but showed differences within each group (Figure 2; Table 4). For example, compounds associated with natural aquatic samples included phenols (\#15, \#17), ${ }^{77}$ benzonitrile (\#14), ${ }^{78}$ and oxidized lignin fragments (\#37, \#42, \#49, \#54, \#56, \#58). ${ }^{54}$ The negative scores on F2 of HAs and FAs from both natural aquatic samples (Zwanenwater and Suwannee River) are in agreement with the smaller size of the source molecules in natural aquatic samples compared to solid samples. $^{26}$ Lower amounts of high molecular weight compounds in FAs from Suwannee River compared to Elliot Soil
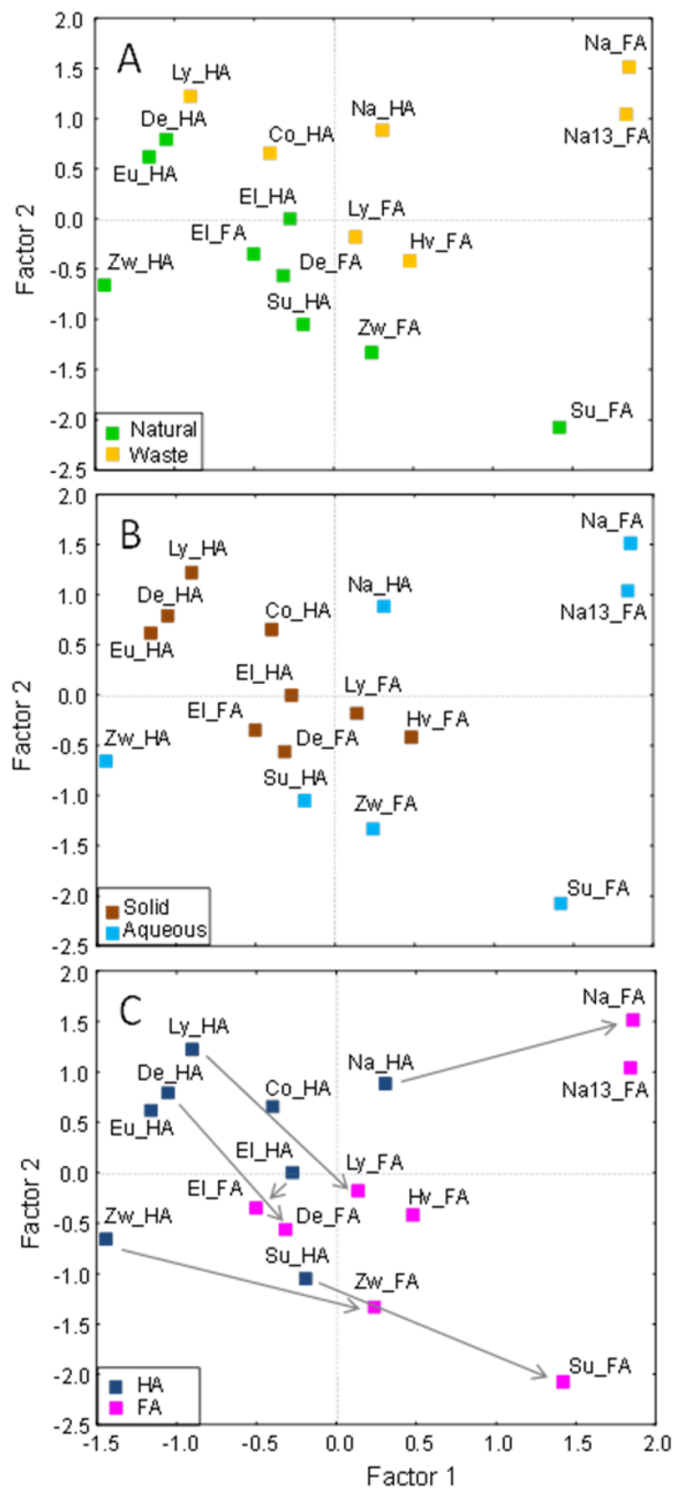

Figure 3. Factor scores displayed for the different samples classes, (A) waste/natural, (B) aqueous/solid and (C) HA/FA. Co = Compost; $\mathrm{De}=$ Devoke; El = Elliot Soil; Eu = Eurosoil; Hv = HVC; Ly = LYS; $\mathrm{Na}=$ Nauerna Influent; Na13 = Nauerna 13AA; Su = Suwannee River; $\mathrm{Zw}=\mathrm{Zwanenwater}$. Arrows connect HA with corresponding FA.

were also found by Nimmagadda and McRae. ${ }^{37}$ The negative scores on F2 of HAs and particularly the FAs from both natural aquatic samples indicate a larger contribution from benzofurans and lower contribution from PAHs (Figure $3 \mathrm{~b}$ ) to aquatic NOM. The fact that the aquatic sample from the landfill waste had a larger contribution from PAHs is explained by the contribution from contaminants. All HAs from solid samples showed negative scores on F1 and positive ones on F2 (Figure $3 \mathrm{~b})$, which corresponds to a contribution from the biopolymers lignin and suberan/cutan (Elliot Soil, Eurosoil, Devoke peat, Compost) and a mixture of lignin and suberan (from woody waste) and plastics in the landfill waste sample (LYS).

3.3.3. HAs vs FAs. The proportion (\% carbon) of each fraction is indicated by the HA/FA ratio (Table 1) and showed a clearly larger contribution from HAs in solid samples and from FAs in aquatic samples. This parallel between FAs and aquatic samples and HAs and solid samples is evidenced by the molecular composition. Differences in the mean relative 
abundance of groups of compounds between aquatic and solid samples generally agreed with that of HAs and FAs (Table 3b). HAs and solid samples generally showed a larger contribution from lignin phenols, $\mathrm{N}$ containing compounds and straight chain aliphatics, while FAs and aqueous samples generally showed a larger contribution from benzofurans, phthalates and PAHs. However, ANOVA showed these differences to be only significant for benzofurans, $\mathrm{N}$ containing compounds and aliphatics.

A general difference between HAs and FAs is also demonstrated by factor analysis. Factor analysis showed a uniform shift between HA and FA from the same sample on both F1 (except Elliot soil) and F2 (except Nauerna influent; Figure 3c), and indicates a generic difference in molecular composition between HAs and FAs, irrespective of its aquatic/ solid or natural/waste source. The generally lower scores on F2 for FAs compared to HAs reflect the smaller size of FAs compared to HAs (Table 4). ${ }^{11}$ The shifts between HA and FA were largest on F1. The interpretation of F1 according to the distribution of pyrolysis products in factor loadings showed that this compositional difference between HAs and FAs was based on the relative contribution from products associated with $\mathrm{BC}$ versus other sources (Table 4), the former being higher in FAs compared to the corresponding HAs. A larger contribution from PAHs and benzofurans in FAs compared to HAs was also found in soil pyrolysates, ${ }^{32,33}$ and is shown here to be a more general feature that distinguishes between these NOM fractions in widely different environments.

The absence of significant differences between the composition of pyrolysates from HAs and FAs (Table 3) is clearly demonstrated by factor analysis. The factor scores show that the difference on F1 is only valid between fractions of a given sample; that is, FA from sample A may be chemically more related to a HA from sample $B$ than to the FA from sample B. For example, Zwanenwater FA had a composition very similar to that of Suwannee River HA, but it differed significantly from Suwannee River FA (scores of F1-F2 projection Figure 3c).

The absence of significant differences between HAs and FAs for most chemical groups is probably related to the widely different sample source, in combination with the multiple sources that individual pyrolysis products may have. For example toluene is abundant in pyrolysates from both charred material and proteins (among other sources), ${ }^{79}$ and accounted for between 20 and $91 \%$ of the benzenes (data not shown), but was the only benzene with different loading in F1-F2 projection (Figure 2). Similarly, for the PAHs, which all showed high positive loadings on F1, a large contribution to the waste samples in both FA and HA interfered with the general tendency observed in factor analysis.

Thus, notwithstanding the fact that benzenes and PAHs showed no significant difference between HAs and FAs (Table $3 \mathrm{~b}$ ), factor analysis showed a general increase of these products (F1) in FAs compared to HAs. The fact that the compounds responsible for this general trend are not the main constituents of the pyrolysates, the sum of which varied between $3.9 \%$ and $44.5 \%$ (Table 3a) is explained by the multiple sources of pyrolysis products in combination with the widely different samples. It is, therefore, recommended to analyze a larger number of samples for each group (natural/waste, solid/ aqueous) to further investigate the boundaries of the molecular similarities and differences between HAs and FAs.
3.3.4. Environmental Significance. Regardless of the source (i.e., solid/aqueous, waste/natural), binding properties of both HAs and FAs have been shown to be remarkably similar. ${ }^{10}$ These properties have been successfully used to model metal binding to HA and FA in soils and waste materials, ${ }^{16,17}$ as well as binding of HA and FA to surface metal groups on mineral surfaces. $^{14,15}$ Nevertheless, substantial variation in binding properties still exists between individual HAs and FAs, with regard to both the binding capacity and affinity of carboxylic and phenolic groups; for example, proton binding affinities varying over more than an order of magnitude. 9,10 The here observed generally larger contribution from aromatic products (PAHs, benzofurans, and most benzenes) in FA compared to the corresponding HA indicates that binding properties of FAs and HAs may, in addition to the number of carboxyl and phenolic groups, be influenced by the molecular structure or architecture. Therefore, we suggest that developing further insight in the molecular structure of HA and FA fractions of NOM can be helpful to identify relationships between HA and FA binding- and molecular- properties. Such relationships may contribute to further our quantitative abilities to model important NOM functions such as metal complexation and association with mineral surfaces.

\section{AUTHOR INFORMATION}

\section{Corresponding Author}

*Phone: +31 653832087; e-mail: schellekens.j@hetnet.nl.

ORCID

Judith Schellekens: 0000-0001-8364-7034

\section{Notes}

The authors declare no competing financial interest.

\section{ACKNOWLEDGMENTS}

Judith Schellekens was supported by FAPESP project 2013/ 03953-9. We thank three anonymous reviewers for their constructive comments.

\section{REFERENCES}

(1) Tiessen, H.; Cuevas, E.; Chacon, P. The role of organic matter in sustaining soil fertility. Nature 1994, 371, 783-785.

(2) Chaplin, B. P.; Reinhard, M.; Schneider, W. F.; Schüt, C.; Shapley, J.; Strathmann, T. J.; Werth, C. J. Critical review of Pd-based catalytic treatment of priority contaminants in water. Environ. Sci. Technol. 2012, 46, 3655-3670.

(3) Jones, M. N.; Brian, N. D. Colloidal properties of humic substances. Adv. Colloid Interface Sci. 1998, 78, 1-48.

(4) Schlesinger, W. H.; Andrews, J. A. Soil respiration and the global carbon cycle. Biogeochemistry 2000, 48, 7-20.

(5) Kögel-Knabner, I. The macromolecular organic composition of plant and microbial residues as inputs to soil organic matter. Soil Biol. Biochem. 2002, 34, 139-162.

(6) Stevenson, F. J. Humus Chemistry. Genesis, Composition, Reactions; John Wiley \& Sons, Inc.: New York, 1982; pp 1-443.

(7) Lehman, J.; Kleber, M. The contentious nature of soil organic matter. Nature 2015, 528, 60-68.

(8) Christl, I.; Kretzschmar, R. Relating ion binding by fulvic and humic acids to chemical composition and molecular size. 1. Proton binding. Environ. Sci. Technol. 2001, 35, 2505-2511.

(9) Milne, C. J.; Kinniburgh, D. G.; Tipping, E. Generic NICADonnan model parameters for proton binding by humic substances. Environ. Sci. Technol. 2001, 35 (10), 2049-2059.

(10) Van Zomeren, A.; Costa, A.; Pinheiro, J. P.; Comans, R. N. J. Proton binding properties of humic substances originating from 
natural and contaminated materials. Environ. Sci. Technol. 2009, 43, 1393-1399.

(11) Chin, Y.; Aiken, G. R; Danielsen, K. M. Binding of pyrene to aquatic and commercial humic substances: the role of molecular weight and aromaticity. Environ. Sci. Technol. 1997, 31, 1630-1635.

(12) Christl, I.; Milne, C. J.; Kinniburg, D. G.; Kretzchmar, R. Relating ion binding by fulvic and humic acids to chemical composition and molecular size. 2. Metal binding. Environ. Sci. Technol. 2001, 35, 2512-2517.

(13) Milne, C. J.; Kinniburgh, D. G.; van Riemsdijk, W. H.; Tipping, E. Generic NICA-Donnan model parameters for metal-ion binding by humic substances. Environ. Sci. Technol. 2003, 37, 958-971.

(14) Weng, L.; van Riemsdijk, W. H.; Hiemstra, T. Adsorption of humic acids onto goethite: Effects of molar mass, $\mathrm{pH}$ and ionic strength. J. Colloid Interface Sci. 2007, 314, 107-118.

(15) Weng, L.; van Riemsdijk, W. H.; Hiemstra, T. Adsorption free energy of variable-charge nanoparticles to a charged surface in relation to the change of the average chemical state of the particles. Langmuir 2006, 22, 389-397.

(16) Van Zomeren, A.; Comans, R. N. J. Contribution of natural organic matter to copper leaching from municipal solid waste incinerator bottom ash. Environ. Sci. Technol. 2004, 38, 3927-3932.

(17) Dijkstra, J. J.; Meeussen, J. C. L.; Comans, R. N. J. Evaluation of a generic multi-surface model for inorganic soil contaminants. Environ. Sci. Technol. 2009, 43, 6196-6201.

(18) Groenenberg, J. E.; Dijkstra, J. J.; Bonten, L. T. C.; de Vries, W.; Comans, R. N. J. Evaluation of the performance and limitations of empirical partition-relations and process based multisurface models to predict trace element solubility in soils. Environ. Pollut. 2012, 166, 98107.

(19) Xiong, J.; Koopal, L. K.; Weng, L.; Wang, M.; Tan, W. Effect of soil fulvic and humic acid on binding of $\mathrm{Pb}$ to goethite-water interface: Linear additivity and volume fractions of HS in the Stern layer. J. Colloid Interface Sci. 2015, 457, 121-130.

(20) Christensen, J. B.; Tipping, E.; Kinniburgh, D. G.; Grøn, C.; Christensen, T. H. Proton binding by groundwater fulvic acids of different age, origins, and structure modeled with the model $\mathrm{V}$ and NICA-Donnan model. Environ. Sci. Technol. 1998, 32, 3346-3355.

(21) Piccolo, A.; Nardi, S.; Concherdi, G. Macromolecular changes of humic substances induced by interaction with organic acids. Eur. J. Soil Sci. 1996, 47, 319-328.

(22) Sutton, R.; Sposito, G. Molecular structure in soil humic substances: the new view. Environ. Sci. Technol. 2005, 39, 9009-9015.

(23) Ritchie, J. D.; Perdue, M. E. Analytical constraints on acidic functional groups in humic substances. Org. Geochem. 2008, 39, 783799.

(24) Mao, J.; Chen, N.; Cao, X. Characterization of humic substances by advanced solid state NMR spectroscopy: Demonstration of a systematic approach. Org. Geochem. 2011, 42, 891-902.

(25) Thorn, K. A.; Cox, L. G. N-15 NMR spectra of naturally abundant nitrogen in soil and aquatic natural organic matter samples of the International Humic Substances Society. Org. Geochem. 2009, 40, 484-499.

(26) Nebbioso, A.; Piccolo, A. Molecular characterization of dissolved organic matter (DOM): a critical review. Anal. Bioanal. Chem. 2013, 405, 109-124.

(27) Sihombing, R.; Greenwood, P. F.; Wilson, M. A.; Hanna, J. V. Composition of size exclusion fractions of swamp water humic and fulvic acids as measured by solid state NMR and pyrolysis-gas chromatography-mass spectrometry. Org. Geochem. 1996, 24, 859873.

(28) Almendros, G.; González-Vila, F. J.; Martín, F.; Sanz, J.; ÁlvarezRamis, C. Appraisal of pyrolytic techniques on different forms of organic matter from a Cretaceous basement in Central Spain. Org. Geochem. 1998, 28, 613-623.

(29) Lu, X. Q.; Hanna, J. V.; Johnson, W. D. Source indicators of humic substances: an elemental composition, solid state ${ }^{13} \mathrm{C} \mathrm{CP} / \mathrm{MAS}$ NMR and Py-GC/MS study. Appl. Geochem. 2000, 15, 1019-1033.
(30) González-Vila, F. J.; Almendros, G.; Tinoco, P.; Rodríguez, J. Nitrogen speciation and pyrolytic patterns of ${ }^{15} \mathrm{~N}$-labelled soil and compost fractions. J. Anal. Appl. Pyrolysis 2001, 58-59, 329-339.

(31) Templier, J.; Derenne, S.; Croué, J.; Largeau, C. Comparative study of two fractions of riverine dissolved organic matter using various analytical pyrolytic methods and a ${ }^{13} \mathrm{C} \mathrm{CP} / \mathrm{MAS} \mathrm{NMR}$ approach. Org. Geochem. 2005, 36, 1418-1442.

(32) Pereira de Assis, C. P.; González-Pérez, J. A.; de la Rosa, J. M.; Jucksch, I.; de Sá-Mendonça, E.; González-Vila, F. J. Analytical pyrolysis of humic substances from a Latosol (Typic Hapludox) under different land uses in Minas Gerais, Brazil. J. Anal. Appl. Pyrolysis 2012, 93, $120-128$.

(33) Martin, F.; Saiz-Jimenez, C.; Cert, A. Pyrolysis gas chromatography-mass spectrometry of soil humic fractions: II The high boiling point compounds. Soil Sci. Soc. Am. J. 1979, 45, 309-312.

(34) Senesi, N.; D'Orazio, V.; Ricca, G. Humic acids in the first generation of EUROSOILS. Geoderma 2003, 116, 325-344.

(35) Lehtonen, T.; Peuravuori, J.; Pihlaja, K. Degradation of TMAH treated aquatic humic matter at different temperatures. J. Anal. Appl. Pyrolysis 2000, 55, 151-160.

(36) Ikeya, K.; Sleighter, R. L.; Hatcher, P. G.; Watanabe, A. Characterization of the chemical composition of soil humic acids using Fourier transform ion cyclotron resonance mass spectrometry. Geochim. Cosmochim. Acta 2015, 153, 169-182.

(37) Nimmagadda, R. D.; McRae, C. Characterisation of the backbone structures of several fulvic acids using a novel selective chemical reduction method. Org. Geochem. 2007, 38, 1061-1072.

(38) Van Zomeren, A.; Comans, R. N. J. Measurement of humic and fulvic acid concentrations and dissolution properties by a rapid batch procedure. Environ. Sci. Technol. 2007, 41, 6755-6761.

(39) Buurman, P.; Nierop, K. G. J.; Kaal, J.; Senesi, N. Analytical pyrolysis and thermally assisted hydrolysis and methylation of EUROSOIL humic acid samples - A key to their source. Geoderma 2009, 150, 10-22.

(40) Berwick, L.; Greenwood, P. F.; Smernik, R. J. The use of MSSV pyrolysis to assist the molecular characterisation of aquatic natural organic matter. Water Res. 2010, 44, 3039-3054.

(41) Klotzbücher, T.; Kaiser, K.; Guggenberger, G.; Gatzek, C.; Kalbitz, K. A new conceptual model for the fate of lignin in decomposing plant litter. Ecology 2011, 92, 1052-1062.

(42) González-Pérez, J. A.; Almendros, G.; de la Rosa, J. M.; González-Vila, F. J. Appraisal of polycyclic aromatic hydrocarbons (PAHs) in environmental matrices by analytical pyrolysis (Py-GC/ MS). J. Anal. Appl. Pyrolysis 2014, 109, 1-8.

(43) Derenne, S.; Quénéa, K. Analytical pyrolysis as a tool to probe soil organic matter. J. Anal. Appl. Pyrolysis 2015, 111, 108-120.

(44) EUROSOILS II Laboratory Reference Materials for Soil-Related Studies; Gawlik, B. M., Muntau, H., Eds.;Environment Institute, Joint Research Centre, European Commission. EUR 18983 EN, 1999.

(45) Van Zomeren, A.; van der Weij-Zuiver, E.; Comans, R. N. J. Development of an automated system for isolation and purification of humic substances. Anal. Bioanal. Chem. 2008, 391, 2365-2370.

(46) Aiken, G. R. Isolation and concentration techniques for aquatic humic substances. In Humic Substances in Soil, Sediment and Water: Geochemistry, Isolation and Characterization; Aiken, G. R, Mc Knight, D. M., Wershaw, R. L., MacCarthy, P., Eds.; Wiley-Interscience: New York, 1985; pp 363-385.

(47) Thurman, E. M.; Malcolm, R. L. Preparative isolation of aquatic humic substances. Environ. Sci. Technol. 1981, 15, 463-466.

(48) Swift, R. S. Organic matter characterization. In Methods of Soil Analysis. Part 3. Chemical Methods; Sparks, D. L., Ed.; Soil Science Society of America: Madison, WI, 1996; pp 1011-1069.

(49) Thompson, S.; Eglinton, G. Composition and sources of pollutant hydrocarbons in the Severn Estuary. Mar. Pollut. Bull. 1978, 9, 133-136

(50) Simoneit, B. R. T.; Mazurek, M. A.; Cahill, T. A. Contamination of the lake Tahoe air basin by high moleculr weight petroleum residues. J. Air Pollut. Control Assoc. 1980, 4, 387-390. 
(51) González-Vila, F. J.; Tinoco, P.; Almendros, G.; Martín, F. Pyrolysis-GC-MS analysis of the formation and degradation stages of charred residues from lignocellulosic biomass. J. Agric. Food Chem. 2001, 49, 1128-1131.

(52) Simoneit, B. R. T.; Rogge, W. F.; Lang, Q.; Jaffé, R. Molecular characterization of smoke from campfire burning of pine wood (Pinus elliottii). Chemosphere: Global Change Sci. 2000, 2, 107-122.

(53) Almendros, G.; Martin, F.; González-Vila, F. J. Effects of fire on humic and lipid fractions in a Dystric Xerochrept in Spain. Geoderma 1988, 42, 115-127.

(54) Kaal, J.; Wagner, S.; Jaffé, R. Molecular properties of ultrafiltered dissolved organic matter and dissolved black carbon in headwater streams as determined by pyrolysis-GC-MS. J. Anal. Appl. Pyrolysis 2016, 118, 181-191.

(55) Kaal, J.; Martínez-Cortizas, A.; Nierop, K. G. J. Characterisation of aged charcoal using a coil probe pyrolysis-GC/MS method optimized for black carbon. J. Anal. Appl. Pyrolysis 2009, 85, 408-416.

(56) Wilson, M. A.; Philip, R. P.; Gillam, A. H.; Gilbert, T. D.; Tate, K. R. Comparison of the structures of humic substances from aquatic and terrestrial sources by pyrolysis gas chromatography-mass spectrometry. Geochim. Cosmochim. Acta 1983, 47, 497-502.

(57) Schulten, H. R.; Schnitzer, M. The chemistry of soil organic nitrogen: a review. Biol. Fertil. Soils 1998, 26, 1-15.

(58) Buurman, P.; Peterse, F.; Almendros Martin, G. Soil organic matter chemistry in allophanic soils: a pyrolysis-GC/MS study of a Costa Rican Andosol catena. Eur. J. Soil Sci. 2007, 58, 1330-1347.

(59) Almendros, G.; Knicker, H.; González-Vila, F. J. Rearrangement of carbon and nitrogen forms in peat after progressive thermal oxidation as determined by solid-state ${ }^{13} \mathrm{C}$ - and ${ }^{15} \mathrm{~N}$-NMR spectroscopy. Org. Geochem. 2003, 34, 1559-1568.

(60) Stankiewicz, B. A.; van Bergen, P. F.; Duncan, I. J.; Carter, J. F.; Briggs, D. E. G.; Evershed, R. P. Recognition of chitin and proteins in invertebrate cuticles using analytical pyrolysis/gas chromatography. Rapid Commun. Mass Spectrom. 1996, 10, 1747-1757.

(61) Eglinton, G.; Hamilton, R. J. Leaf epicuticular waxes. Science $1967,156,1322-1325$.

(62) Kolattukudy, P. E. Biopolyester membranes of plants: cutin and suberin. Science 1980, 208, 990-1000.

(63) Derenne, S.; Largeau, C.; Casadevall, E.; Berkaloff, C.; Rousseau, B. Chemical evidence of kerogen formation in source rocks and oil shales via selective preservation of thin resistant outer walls of microalgae: Origin of ultralaminae. Geochim. Cosmochim. Acta 1991, $55,1041-1050$.

(64) Miranda, M.; Cabrita, I.; Pinto, F.; Gulyurtlu, I. Mixtures of rubber tyre and plastic wastes pyrolysis: A kinetic study. Energy 2013, $58,270-282$.

(65) Marques, F. A.; Buurman, P.; Schellekens, J. Vidal-Torrado. Molecular chemistry in humic ferralsols from Brazilian Cerrado and forest biomes indicates a major contribution from black carbon in the subsoil. J. Anal. Appl. Pyrolysis 2015, 113, 518-528.

(66) de Silva Oliveira, D. M.; Schellekens, J.; Cerri, C. E. Molecular characterization of soil organic matter from native vegetationpasture-sugarcane transitions in Brazil. Sci. Total Environ. 2016, $548-549,450-462$.

(67) Schellekens, J.; Buurman, P.; Kuyper, T. W.; Abbott, G. D.; Pontevedra-Pombal, X.; Martínez-Cortizas, A. Influence of source vegetation and redox conditions on lignin-based decomposition proxies in graminoid-dominated ombrotrophic peat (Penido Vello, NW Spain). Geoderma 2015, 237-238, 270-282.

(68) Pastorova, I.; Arisz, P. W.; Boon, J. J. Preservation of d-glucoseoligosacharides in cellulose chars. Carbohydr. Res. 1993, 248, 151-165.

(69) Knicker, H. How does fire affect the nature and stability of soil organic nitrogen and carbon? A review. Biogeochemistry 2007, 85, 91118.

(70) Pouwels, A. D.; Eijkel, G. B.; Boon, J. J. Curie-point pyrolysis high-resolution gas chromatography/mass spectrometry of microcrystalline cellulose. J. Anal. Appl. Pyrolysis 1989, 14, 237-280.
(71) Hudson, J. R.; Morgan, S. L.; Fox, A. Quantitative pyrolysis gas chromatography of bacterial cell walls. Anal. Biochem. 1982, 120, 5965 .

(72) Meyer, S.; Cartellieri, S.; Steinhart, H. Simultaneous determination of PAHs, hetero-PAHs ( $\mathrm{N}, \mathrm{S}, \mathrm{O})$, and their degradation products in creosote-contaminated soils: Method development, validation, and application to hazardous waste sites. Anal. Chem. 1999, 71, 4023-4029.

(73) Filley, T. R.; Cody, G. D.; Goodell, B.; Jellison, J.; Noser, C.; Ostrofsky, A. Lignin demethylation and polysaccharide decomposition in spruce sapwood degraded by brown rot fungi. Org. Geochem. 2002, $33,111-124$

(74) Simoneit, B. R. T.; Medeiros, P. M.; Didyk, B. M. Combustion products of plastics as indicators for refuse burning in the atmosphere. Environ. Sci. Technol. 2005, 39, 6961-6970.

(75) Jaffé, R.; Ding, Y.; Niggeman, J.; Vähätalo, A. V.; Stubbins, A.; Spencer, R. M.; Campbell, J.; Dittmar, T. Global charcoal mobilization from soils via dissolution and riverine transport to oceans. Science 2013, 340, 345-347.

(76) Kim, S.; Kaplan, L. A.; Benner, R.; Hatcher, P. G. Hydrogendeficient molecules in natural riverine water samples- evidence for the existence of black carbon in DOM. Mar. Chem. 2004, 92, 225-234.

(77) Page, D. W.; van Leeuwen, J. A.; Spark, K. M.; Mulcahy, D. E. Application of pyrolysis-gas chromatography/mass spectrometry for characterisation of dissolved organic matter before and after alum treatment. J. Anal. Appl. Pyrolysis 2003, 67, 247-262.

(78) Sýkorová, I.; Havelcová, M.; Trejtnarová, H.; Matysová, P.; Văsícek, M.; Kríbek, B.; Sucký, V.; Kotlík, B. Characterization of organic matter in dusts and fluvial sediments from exposed areas of downtown Prague, Czech Republic. Int. J. Coal Geol. 2009, 80, 69-86. (79) Schellekens, J.; Barberá, G. G.; Buurman, P. Potential vegetation markers - analytical pyrolysis of modern plant species representative of Neolithic SE Spain. J. Archaeol. Sci. 2013, 40, 365-379. 